\title{
ダイエット目標が目標/誘惑に関連した対象の 非意識的な評価に及ぼす影響
}

\section{樋口 収 ${ }^{1}$ 埴田 健司 一橋大学 小林 麻衣 東洋大学 北村 英哉 関西大学}

\author{
The effect of priming of a diet goal on the implicit evaluations of goal and temptation relevant targets \\ Osamu Higuchi, Kenji Hanita (Hitotsubashi University), Mai Kobayashi (Toyo University), \\ and Hideya Kitamura (Kansai University)
}

\begin{abstract}
This research investigated how to overcome temptations and protect high-order goals while pursuing a goal. We hypothesized that in order to promote self-regulation, individuals non-cousciously engage in asymmetric evaluative responses to goal-relevant and temptation-relevant stimuli. In an experiment, we manipulated either diet goal or academic goal. Then, we measured evaluations of either sugary drinks (e.g., Coke, Fanta) or healthy drinks (e.g., Healthya Green Tea, Black Oolong Tea). The results showed that participants who activated a diet goal had significantly more positive evaluations of healthy drinks than sugary drinks. In addition, this tendency was moderated by the means of dieting (i.e., only participants who cut down on sweets when going on a diet). The role of non-consious asymmetric evaluations for selfregulation is discussed.
\end{abstract}

Key words: self-regulation, counteractive control theory, goal/ temptation, habit, implicit evaluation.

The Japanese Journal of Psychology

2012, Vol. 83, No. 4, pp. 363-368

美容や健康面への懸念から，体重の管理に対する関 心は非常に高く（例えば，平成 21 年厚生労働省によ る国民健康・栄養調査によれば, 体重の管理に関する 関心は男女ともに $65 \%$ 以上), またダイエットに関連 した出版物も多く出されている。肥満傾向の問題は欧 米ほど深刻ではないとの指摘もあるが, 当該調査によ れば，肥満者の割合はそれでも約 $30 \%$ と低くはない。

肥満の一因としては, 食べたいという誘惑を抑えら れないことが挙げられる（Lowe \& Butryn, 2007)。い いかえれば，太りすぎないようにするためには，食べ 物への誘惑を抑える必要がある。こうした誘惑への対 処は, 自己制御（self-regulation）の問題として古く から心理学者の関心を集めてきた（Ainslie, 2001; Loewenstein, 1996; Mischel, Cantor, \& Feldman, 1996)。 自己制御研究では従来意識の働きが強調されてきた

Correspondence concerning this article should be sent to: Osamu Higuchi, Graduate School of Social Sciences, Hitotsubashi University, Naka, Kunitachi 186-8601, Japan. (e-mail: ohgc. 29 (a)gmail.com)

実験の計画・実施にあたり, 帝京大学文学部心理学科の辻 千恵実さん, 新井田 恵美さん, 村田さくらさんには大変お世 話になりました。記して感謝致します。
が，近年では非意識的な自己制御過程が注目されてい る (Aarts, 2007; Bargh, Gollwitzer, \& Oettingen, 2010)。本研究では, ダイエットにおける非意識的な 自己制御過程を扱い，甘い物などの誘惑に対して，ど のような場合に非意識的に対処することができ，どの ような場合にできないのかを明らかにする。

\section{誘惑への対処}

誘惑への対処方略について言及した理論の一つに反 作用的統制理論 (counteractive control theory) があ る (Fishbach \& Trope, 2007)。この理論は, 自己制御 をする際，意識的に目標と関連した物の価值を高めた り（Trope \& Fishbach, 2000), 誘惑と関連した物の価 值を低めたり（Myrseth, Fishbach, \& Trope, 2009）す ることを想定している。例えば Myrseth et al. (2009) は，ジムから出てきた人たちを実験参加者として，チ ヨコレート・バーあるいはヘルシー・バーを提示し, どちらかを選択するように依頼した。このとき，半数 の実験参加者には選択前にそれぞれのバーの魅力を評 価するように求め, 残りの半数の実験参加者には選択 後にそれぞれのバーの魅力を評価するように求めた。 すると, 選択前ではチョコレート・バーの魅力をへル 
シー・バーの魅力よりも低く評価していた。一方，選 択後はバーの魅力に差はみられず, 選択前のへルシ ー・バーと同程度に高く評価していた。 Myrseth et al. （2009）はこの結果を，選択前はチョコレート・バー を選ばないように自己制御する必要があったために,

当該バーの魅力を下げたと解釈している。

近年では，こうした自己制御過程が非意識的にも生 じ得ることが示されている (Fishbach, Zhang, \& Trope, 2010)。ある実験では, まず乱文再構成課題に よって学業目標の活性化を操作している。次に, 逐次 プライミング (sequential priming) を実施し，目標や 誘惑に関連した物に対する非意識的な評価を測定して いる。具体的には, 学業関連語（例えば, 図書館）あ るいは遊び関連語（例えば，映画）を閾下でプライミ ングした後に, ポジティブ単語（例えば，愛）あるい はネガテイブ単語（例えば, がん）を提示し，単語の ベイレンス（valence）判断を求めた。すると, 学業 目標が活性化していた条件では, 学業関連語がプライ ミングされるとポジティブ単語に速く反応し, 誘惑関 連語がプライミングされるとネガティブ単語を速く同 定していた（学業目標が活性化していないときには, こうした傾向はみられなかった)。この結果は, 自己 制御をする際，目標と関連した物をポジティブに，誘 惑と関連した物をネガティブに非意識的に評価するこ とを示唆している。

\section{本研究の視点}

Fishbach et al.（2010）の研究をダイエットの文脈 で考えると, ダイエット目標が活性化したときには， ダイエットに役立つ物はポジティブに, ダイエットを 阻害する誘惑物はネガティブに非意識的に評価すると 考えられる。

ただし，誰もがこうした非意識的な評価を行えるか どうかは明らかではない。この点について考えるため には，非意識的な自己制御過程について考える必要が ある。一般に，非意識的な自己制御は目標表象の活性 化という観点から説明される。すなわち, 目標は目標 追求のための手段と連合しており（Vallacher \& Wegner, 1987)，目標が活性化するとその手段も活性 化するため, 非意識的に目標を追求することができる (Aarts, 2007)。実際 Fishbach et al.（2010）において, 目標や誘惑に関連した対象の評価が非意識的に変化し たのも，目標の活性化に伴って手段が活性化し，当該 手段に沿うように評価が変化したためだと解釈でき る。

このように考えると，対象に対する評価を非意識的 に変えられるのは，目標と当該対象に関する手段とが 連合している者といえる。ダイエットの文脈でいえ ば，例えばダイエット目標と甘い物を我慢するという 手段が連合している人だけが甘い物に対する評価を非
意識的に変えることができると予測される。

本研究ではこのことを検討するために, ダイエット をする際の習慣に着目する。一般に，習慣的にとられ ている手段ほど活性化しやすいため（Aarts＆ Dijksterhuis, 2000), 対象と関連した習慣をもつ者は 非意識的に評価を変えられるだろう。つまり，ダイエ ットするとき習慣的に甘い物を我慢する人は，当該手 段が活性化しやすいため, 食べ物（健康的な物や甘い 物）に対する評価を非意識的に変化させるだろう。一 方，そうした習慣がない人は当該手段が活性化しにく いため, 食べ物に対する評価は非意識的には変わらな いだろう。

\section{実験の概要}

以上の議論から, 本研究は非意識的な自己制御にお ける，目標や誘惑に関連した対象に対する非意識的な 評価に，行為者のもつ習慣が及ぼす影響を検討する。 実験では Fishbach et al.（2010）と同様に, 非意識的 にダイエット目標を活性化させた後, 目標や誘惑に関 連した対象に対する評価を非意識的に測定した。

目標の操作は, Aarts, Gollwitzer, \& Hassin (2004) に倣って, 目標追求をする他者の行動文を提示した。 具体的には，ダイエットをしている人の文章（ダイエ ット目標）あるいは語学の勉強をしている人の文章 （勉強目標）を読ませることで, ダイエット目標の操 作を行った (Appendix) ${ }^{2}$ 。

また非意識的な評価は, 感情䛊帰属手続き (Affect Misattribution Procedure：以下 AMP とする）を用い て測定した（及川・及川・青林, 2009; Payne, Cheng, Govorun, \& Stewart, 2005)。AMP は逐次プライミン グの一種であり，潜在的な態度を測定するものである (Payne et al., 2005)。AMP では, 最初に写真（プライ 厶) が提示され，次に未知の文字（ターゲット）が提 示される。そして, その文字に対する印象がポジティ ブかネガティブかを評価するというものである。この ときプライムに対する評価的反応がターゲットに対す る印象に非意識的に誤帰属されると想定されている。 本研究では, 目標や誘惑に関連した対象に対する非意 識的な評価を測定するためにこの AMPを用いた。 AMP のプライムにはペットボトル飲料の写真を用い た。具体的には, ダイエット目標と関連した対象とし

\footnotetext{
2 ダイエット目標の対照条件として勉強目標条件を設定し, 目標を操作するための文章内では, どちらの条件でも登場人物 がダイエット目標あるいは勉強目標を頑張って達成しようとす るように記述した。このように勉強目標条件を対照条件とした のは, 本研究の結果が達成目標の活性化によるものだという代 替説明を排除するためである。すなわち, 達成目標が活性化す れば健康になろうとしたり, 勉強を頑張ろうとするわけではな く, あくまでどのような達成目標が活性化するかが重要である ことを示す意味があった。
} 
て健康的な飲料を, 誘惑と関連した対象として甘い飲 料を提示した。このように飲料で統一したのは, 提示 する写真の形状の違いが評価に及ぼす影響を統制する ためである。

ダイエットをする際の習慣となっている手段につい ては, ダイエットをする際に甘い物を我慢するかそれ とも別の手段をとるのかを直接的に尋ねた。

仮説は次のと抢りである。ダイエット目標が活性化 した場合には, 勉強目標が活性化された場合に比べ て，甘い飲料よりも健康的な飲料を非意識的にポジテ イブに評価するだろう。ただし上記の傾向は，ダイエ ットを行うときに習慣的に甘い物を我慢している実験 参加者に限られるだろう。

\section{方法}

実験参加者 大学生 65 名（男性 22 名, 女性 43 名; 平均年齢 19.80 歳）であった。このうち実験者の指示 に従わなかった者 2 名, AMP に対する平均反応潜時 が外れ值 $(M+3 S D)$ だった者 1 名と外国人留学生 2 名を除いた 60 名（男性 21 名, 女性 39 名; 平均年齢 19.69 歳) を分析対象とした。

実験計画 2（習慣：あり・なし) $\times 2 （$ 目標：ダイ エット・勉強 $) \times 2$ (飲料：甘い飲料・健康飲料)。最 初の二つが参加者間要因, 最後の飲料が参加者内要因 の混合計画であった。なお各条件の人数は, 習慣あ り・ダイエット目標条件 17 名, 習慣あり・勉強目標 条件 17 名, 習慣なし・ダイエット目標条件 13 名, 習 慣なし・勉強目標条件 13 名であった。

手続き パソコンを用いた講義内で実験を実施し た。実験は“瞬間的な判断に関する課題であり，質問 紙とパソコンを用いて, 瞬間的な判断能力を調べる” と説明した。最初に質問紙で瞬間的な判断能力を調心゙ ると説明して，質問紙を配布した。この課題では，限 られた時間内にどの程度文章を読んで理解できたのか が問われると説明し，制限時間が過ぎたらその文章に 関する質問に答えてもらうと告げた（制限時間は具体 的には伝えなかった)。実際には，この課題は目標 (ダイエット・勉強) を操作するためのものであり, 2 種類の質問紙がランダムに配布された。なお両条件と も，目標達成に励む人物の日記のような物を提示した (Appendix)。制限時間（1 分 10 秒）が過ぎたら読む のをやめるように実験参加者に伝え，次のページにあ る質問に答えるように求めた。質問は, 文章中に出て きた漢字（例えば, 健康あるいは勉強) やカタカナ （例えば，エアロビクスあるいはルーム・レッスン） を一つずつ回答するものであっだ。

この課題は, 実験参加者が実際に文章をきちんと読んだか どうかを確かめるために設けた。その結果, すべての実験参加 者が文章にあった語を回答していた。そのため,この課題によ って分析対象外とされた実験参加者はいなかった。
質問紙に対する回答が済み次第，パソコン上での瞬 間的な判断に関する課題に移るように求めた。課題へ の取り組み方はすべてパソコン上で教示され，各自の ペースで答えるように伝えられた。この課題が AMP であり，飲料に対する非意識的な評価が測定された。 AMP では, パソコン上に示される文字の印象をでき る限り速く回答するように求めた。その際, 文字は現 れてすぐに消えるので, 文字が現れる合図として直前 に写真が出ると説明した。そして写真については判断 する必要はなく，無視するように教示した。課題が開 始されると，まずプライム刺激が $200 \mathrm{~ms}$ 提示され, ブランク画面 $100 \mathrm{~ms}$ をはさんでターゲット文字（ア ルメニア文字) が $100 \mathrm{~ms}$ 提示された4。ターゲット文 字が消えるとパタンマスクが提示され, 実験参加者は この間にターゲット文字の印象が良いか悪いかをでき る限り速く判断するように求められた。具体的には, 良いと判断した場合には Enter キーを, 悪いと判断し た場合には $\mathrm{Tab}$ キーを押すように教示された。そし て判断が終ると $1000 \mathrm{~ms}$ の試行間間隔をはさみ, 次 の試行へと移った。なお,この AMP の制御には Hot Soup Processor 2.61 が用いられた。

実験参加者は課題に慣れるための練習試行を 4 回行 った後, 本試行へと移った。練習試行を行う際には, その旨がパソコン画面上で明示され, 練習試行を終え ると, 次からが本試行であるとの説明が同様にパソコ ン画面上でなされた。プライムには甘い飲料六つ（例 えば, ドリンク A (コーラ), ドリンク B (ファンタ オレンジ)）と健康的な飲料六つ（例えば, ドリンク C (ヘルシア緑茶), ドリンク D (黒烏龍茶) ) が用い られた。そしてそれらを各 2 試行ずつ, 計 24 試行が 行われた。プライムとターゲットの組み合わせ，およ び順序は実験参加者ごとにランダムであった。また練 習試行で用いられたプライムとターゲットは，本試行 ではいずれも用いられなかった。

パソコン課題が終了すると, 最後に実験に関するア ンケートに答えるように求めた。このアンケートで は，実験に対する気づきとダイエットをする際の習慣 についての質問が行われた。実験に関する気づきは, 自由記述で回答を求めた。その結果, 今回の実験の目 的に気づいた者はいなかった。またダイエットをする 際の習慣的な手段については“あなたは, ダイエット をしようと思ったとき，どのようにダイエットをして いますか。あてはまるもの全てに○をつけて下さい。” という質問に対して“1. 炭水化物を我慢する 2. 甘 いものを我慢する 3. 運動する 4. それ以外（）” という選択肢を提示した（それ以外を選択する場合に は, 括弧内に具体的に方法を記述させた)。その他,

\footnotetext{
4 本研究では, Bargh \& Chartrand（2000）にもとづき，SOA は $300 \mathrm{~ms}$ 以下になるようにした。
} 
今回の AMP は飲料をターゲットとしており，飲料に 対する反応に実験時ののどの渇きが影響を及ぼす可能 性が考えられたため, 実験時ののどの渇きの程度につ いて 1 項目（“あなたは，今どのくらい，のどが渇い ていますか”）9件法で尋ねた。

アンケートに対する回答を全員が終えたことを確認 した上で最初の課題として用いた質問紙とアンケート 用紙を回収した。その後，実験に関するデブリーフィ ングを行い，実験参加に対する謝意を述べてから解散 した。

\section{結果}

本研究の仮説は“ダイエット目標が活性化した場合 には，勉強目標が活性化された場合に比べて，甘い飲 料よりも健康的な飲料を非意識的にポジティブに評価 するだろう。またこの傾向は，ダイエットをするとき 甘い物を我慢するという手段を習慣的にとる人に限ら れるだろう”というものであった。

これらの仮説を検討するため，まずダイエットの手 段として甘い物を我慢するという手段をとる群（習慣 あり群）26名（男性 7 名, 女性 19 名; 平均年齢 19.54 歳）とそのような手段をとらない群（習慣なし群） 34 名（男性 14 名, 女性 20 名; 平均年齢 19.82 歳）に分 けた5。次にAMPにおける甘い飲料に対するポジテ イブ反応率と健康的な飲料に対するポジティブ反応率 を求めた。ポジティブ反応率は, 甘い飲料, 健康的な 飲料に対する各 12 試行のうち何試行で良いと判断し たのかその割合を算出した（良いと判断した回数 $\div$ 12)。

仮説を検討するために，のどの渇きの程度を共変量

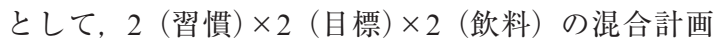
の共分散分析を行った 6 。その結果， 2 次の交互作用

この結果，甘いものを我慢するという手段をとる男性の数 は，そうではない手段をとる男性に比べて少なかった。このよ うな群間の性差が実験結果に影響を及ぼしていないかを検討す るために, これ以降で示す分析で性別を要因に含めて行ったが, 性別の影響は主効果，交互作用効果いずれもみられなかった。 そのため, 以降で示す分析では性別を要因には含めずに行った ものを示す。

6 本研究の実験手続きでは, 共変量であるのどの渴きの程度 が従属変数の後に測定されたものであるため, それらが操作と して他の独立変数や従属変数への回答の影響を受けている可能 性がある。そこでこの点について確認するために，まず，のど の渴きの程度を従属変数として 2 (習慣) $\times 2 （$ 目標 $)$ の分散分析 を行った。その結果, 主効果, 交互作用効果ともに有意ではな かった（順に $F(1,56)<1, n s, F(1,56)<1, n s, F(1,56)=2.29$, $n s)$ 。またのどの渇きの程度と甘い飲料や健康飲料に対するポジ ティブ反応率の間にも相関はみられなかった（順に $r=-.05$, $n s, r=.11, n s)$ 。これらの結果は, のどの渇きの程度が独立変数 の操作や従属変数への回答によって一定の影響を受けていなか ったことを示唆している。
効果のみが有意であった $(F(1,54)=4.37, p<.05$ : Figure 1)。そこで習慣の有無ごとに単純交互作用効 果の検定を行った。すると, 習慣あり群でのみ単純交 互作用効果が有意であった $(F(1,54)=5.48, p<.05)$ 。 そこでさらに習慣あり群の中で目標ごとに単純・単純 主効果検定を行ったところ, 勉強目標条件では飲料の 効果は有意ではなく $(F(1,54)=1.68, n s)$ ダイエッ 卜目標条件で飲料の効果が有意であった $(F(1,54)=$ $10.40, p<.05)$ 。すなわち, 勉強目標条件では甘い飲 料と健康的な飲料に対するポジティブ反応率に有意差 はみられず $(M=.57, M=.51)$, ダイエット目標条件 では甘い飲料よりも健康的な飲料に対するポジティブ な反応率が有意に高かった $(M=.50, M=.60)$ 。なお 習慣なし群での単純交互作用効果は有意ではなく $(F(1,54)=3.20, n s)$, 勉強目標条件 $(M=.59, M=.54)$ でもダイエット目標条件 $(M=.51, M=.56)$ でもポ ジティブ反応率に有意差はみられなかった。

次に目標ごとに単純交互作用効果の検定を行ったと ころ, 勉強目標条件では単純交互作用効果は有意では なかったが $(F(1,54)=3.39, n s)$, ダイエット目標条 件では単純交互作用効果が有意であった $(F(1,54)=$ 6.01, $p<.05)$ 。そこでさらにダイエット目標条件の中 で習慣ごとに単純・単純主効果検定を行ったところ, 習慣なし群では飲料の効果は有意ではなく $(F(1,54)=1.93, n s)$, 習慣あり群では飲料の主効果 が有意であった $(F(1,54)=10.40, p<.05)$ 。

以上の結果をまとめると，ダイエット目標が活性 化しているとき，甘い飲料よりも健康的な飲料に対 して非意識的にポジティブな評価をしていた。ただ し，そのような傾向がみられたのはダイエットをす る際習慣的に甘い物を我慢する人たちに限られてい た。これらの結果は, 本研究の仮説を支持するもので あった。

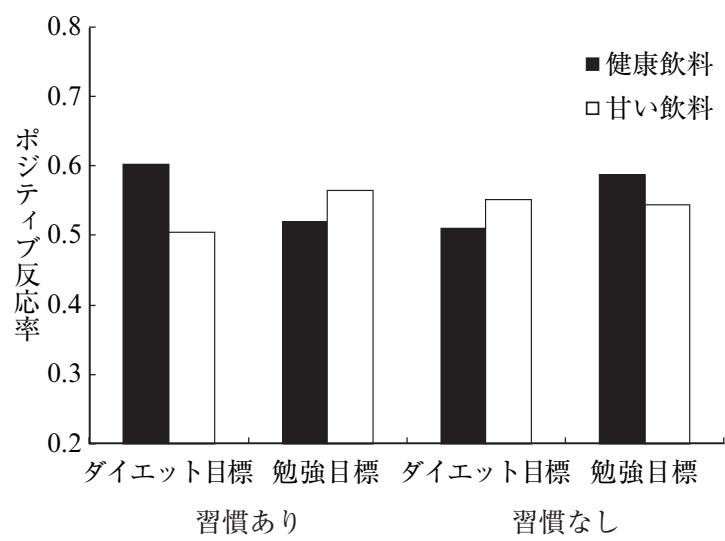

Figure 1. 条件ごとの各飲料に対するポジティブ反応率 注） ポジティブ反応率の得点範囲は 0.0-1.0 である。 


\section{考察}

本研究は，非意識的な自己制御過程における，目標 あるいは誘惑に関連した対象に対する非意識的な評価 が, 行為者のもつ習慣によって調整されるかどうかを 検討したものである。本研究では, 目標の活性化に伴 って手段が活性化することによって，上記のような非 意識的な評価が生じると想定した。そして, どのよう な手段が活性化するかは, 行為者がもつ習慣に依存す ると考えられることから，目標の活性化が非意識的な 評価に及ぼす影響は習慣が調整するという仮説をたて た。その結果, 習慣あり・ダイエット目標条件での み, 甘い飲料よりも健康的な飲料が非意識的にポジテ イブに評価されていた。この結果は, 本研究の仮説を 支持するものであった。

こうした非意識的な自己制御過程によって生じる評 価はこれまであまり検討されてこなかった。本研究 は，そうした研究の一つである Fishbach et al. (2010) とは異なる手続きを用いてこのことを追認した。また 本研究では, 目標と手段の連合 (Vallacher \& Wegner, 1987）という観点から, 行為者のもつ習慣が非意識的 な評価を調整すると予測し，検討を行った。こうした 観点からの調整要因の検討はこれまでなく，そのよう な意味で本研究には一定の意義があると思われる。

加えてこうした知見は, 意識的な自己制御の失敗の 一因を提供するかもしれない。冒頭でも述べたよう に，自己制御をするために，意識的に誘惑に関連した 対象をネガティブに評価することがある（Myrseth et al., 2009)。しかし，こうした試みは常に成功するわ けではない (Erskine, 2008)。その理由の一つとして, 非意識的な評価の問題が挙げられるかもしれない。例 えばダイエットをする際甘い物を我慢するといった手 段を習慣的にとらない者は, 非意識的に甘い物をネガ ティブに評価するわけではない。そうした人たちにと って，甘い物を意識的にネガティブに評価しようとす ることは難しいのかもしれない。ただし，この点につ いては本研究からは明らかではない。そのため, 今後 検討する必要がある。

このように本研究にはいくつか意義を見出すことが できるものの, 限界もある。第一に, 本研究では目標 と手段の連合という観点から, 習慣の有無が非意識的 な評価を調整すると予測していたが，甘い物を我慢す るという習慣がなくとも，ダイエットをするには甘い 物を我慢する必要があるという知識をもっているため に, それらが連合している可能性はある。すなわち, 習慣なし・ダイエット目標条件の実験参加者の中に も，甘い物を我慢するという手段が活性化した実験参 加者がいるかもしれない。そのような場合，当該条件 でも非意識的に評価が変わっていてもよいはずであ る。
ただし，この可能性については，手段の抑制という 観点から排除できるかもしれない。先行研究によれ ば，目標が活性化したとき，その目標と連合するすべ ての手段が活性化するわけではない。むしろ，ある手 段が活性化すると他の手段は抑制される（Danner, Aarts, \& de Vries, 2007; McCulloch, Aarts, Fujita, \& Bargh, 2008)。活性化拡散の原理から, 目標との連合 強度が強い手段ほど活性化しやすいため（Zhang＆ Tu，2011）, 習慣化している手段ほど活性化しやす く，他の手段は抑制されると考えられる。そのように 考えると, 習慣なし・ダイエット目標条件の実験参加 者は，甘い物を我慢するという手段は（かりに目標と 連合していても）抑制されていたはずであり，そのた めに非意識的な評価は変わらなかったと考えられる。 ただし，この可能性については今後検討が必要であ る。

第二に，甘い物を我慢するという手段をとるダイエ ット目標条件の実験参加者は, 甘い飲料よりも健康的 な飲料をポジティブに評価していたが，この結果はあ くまで相対的な評価であり，前者をネガティブに評価 したのか, 後者をポジティブに評価したのか定かでは ない。この点については, 中性刺激も用意して検討す る必要がある。また, 当該条件の実験参加者が本当に 自己制御できているのか, 例えば実際に甘い物を控え るという行動をとるのかどうか, 明らかではない。こ の点についても改めて検討する価值はあるだろう。

本研究は，誘惑に負けずに自己制御を行うための一 つの方略として, 非意識的な自己制御過程について検 討した。実験の結果, 自己制御をする際, 目標や誘惑 に関連した対象に対する非意識的な評価が変わり得る ことが示された。こうした過程は, 有限な心的資源を 枯渇させない非常に効率的な過程であり, 重要な過程 であると考えられる。ただし，そうした非意識的な自 己制御は常に生じるわけではない。本研究の文脈から いえば，それはあくまで目標を達成するための手段が 習慣化されている場合に限られるといえる。

\section{引用文献}

Aarts, H. (2007). On the emergence of human goal pursuit: The nonconscious regulation and motivation of goals. Social Psychology and Personality Compass, 1, 183-201.

Aarts, H., \& Dijksterhuis, A. (2000). Habits as knowledge structures: Automaticity in goal-directed behavior. Journal of Personality and Social Psychology, 78, 53-63.

Aarts, H., Gollwitzer, P. M., \& Hassin, R. R. (2004). Goal contagion: Perceiving is for pursuing. Journal of Personality and Social Psychology, 87, 23-37.

Ainslie, G. (2001). Breakdown of will. New York: 
Cambridge University Press.

Bargh, J. A., \& Chartrand, T. L. (2000). The mind in the middle: A practical guide to priming and automaticity research. In H. T. Reis \& C. M. Judd (Eds.), Handbook of research methods in social and personality psychology. New York: Cambridge University Press. pp. 253-285.

Bargh, J. A., Gollwitzer, P. M., \& Oettingen, G. (2010). Motivation. In S. T. Fiske, D. T. Gilbert, \& G. Lindzey (Eds.), Handbook of social psychology. 5th ed. New York: Wiley. pp. 268-316.

Danner, U. N., Aarts, H., \& de Vries, N. K. (2007). Habit formation and multiple means to goal attainment: Repeated retrieval of target means causes inhibited access to competitors. Personality and Social Psychology Bulletin, 33, 1367-1379.

Erskine, J. A. K. (2008). Resistance can be futile: Investigting behavioural rebound. Appetite, 50, 415-421.

Fishbach, A., \& Trope, Y. (2007). Implicit and explicit mechanisms of counteractive self-control. In J. Shah \& W. Gardner (Eds.), Handbook of motivation science. New York: Guilford Press. pp. 281294.

Fishbach, A., Zhang, Y., \& Trope, Y. (2010). Counteractive evaluation: Asymmetric shifts in the implicit value of conflicting motivations. Journal of Experimental Social Psychology, 46, 29-38.

Loewenstein, G. (1996). Out of control: Visceral influences on behavior. Organizational Behavior and Human Decision Processes, 65, 272-292.

Lowe, M. R., \& Butryn, M. L. (2007). Hedonic hunger: A new dimention of appetite? Physiology and Behavior, 91, 432-439.

McCulloch, K. C., Aarts, H., Fujita, K., \& Bargh, J. A. (2008). Inhibition in goal systems: A retrievalinduced forgetting account. Journal of Experimental
Social Psychology, 44, 857-865.

Mischel, W., Cantor, N., \& Feldman, S. (1996). Principles of self-regulation: The nature of willpower and self-control. In E. T. Higgins \& A. W. Kruglanski (Eds.), Social psychology: Handbook of basic principles. New York: Guilford Press. pp. 329360.

Myrseth, K. O., Fishbach, A., \& Trope, Y. (2009). Counteractive self-control: When making temptation available makes temptation less tempting. Psychological Science, 20, 159 -163.

及川 晴 · 及川 昌典 · 青林 唯 (2009). 感情誤帰属手 続きによる潜在目標の測定一一潜在および顕在目 標による日常行動の予測——教育心理学研究, 57, 192-200.

(Oikawa, H., Oikawa, M., \& Aobayashi, T. (2009). Affect misattribution procedure as an implicit goal measure: Implicit and explicit goals and daily behavior. Japanese Journal of Educational Psychology, 57, 192-200.)

Payne, B. K., Cheng, C. M., Govorun, O., \& Stewart, B. (2005). An inkblot for attitudes: Affect misattribution as implicit measurement. Journal of Personality and Social Psychology, 89, 277-293.

Trope, Y., \& Fishbach, A. (2000). Counteractive selfcontrol in overcoming temptation. Journal of Personality and Social Psychology, 79, 493-506.

Vallacher, R. R., \& Wegner, D. M. (1987). What do people think they're doing? Action identification and human behavior. Psychological Review, 94, 315 .

Zhang, Y., \& Tu, Y. (2011). The impact of associative strength on performance in goal pursuit. Journal of Experimental Social Psychology, 47, 1088-1095.

- 2011. 10.26 受稿, 2012.3.3 受理——

Appendix

健康である（外国語が話せる）ことは，現代社会において，何より大事だと分かっていますが，実際，健康 （語学の勉強）のために何かをする事って少ないですよね?

皆さんは, 健康（語学の勉強）のために, 何かをされていますか? 私は, 週 1 回のペースでジム（語学教 室）に通っています。運動（語学）を数年間していなかった私は“体を引きしめるエアロビクス（ルーム・レッ スン)”という講座がとても激しいモノだと想像できず，気軽に希望を出してしまいました。

本格的に開始し，当初は“こんな羽目になるとは…”. と，悔やみまくっていたんです。何故かと言うと，題 名からは想像できない, しんどさだったからです。“ひえー, 帰りたい!!”と思いながら, 先生や他の人たちと 一緒の動きができず（先生や他の人たちとの会話についていけず），1 時間がアッという間に過ぎ去っていきま した。次回から行くのをどうしょうかと迷ったのですが, 25 回コースで全額納付してしまっていたため, 嫌々 ながらも行くことを決心したのでした。行かなければならないと思うと, 朝から憂馤になるぐらい嫌だったので すが，回を重ねるごとに同じ動き（会話）ができるようになり，できるようになると，とても楽しくなりまし た。今では, 体重も少しずつ減り（自分が黙っている時間も減り），でももう少し健康のために運動をしたい (語学力をつけたい) と思い, iPodに音楽（語学のプログラム）をいれて，聞きながらウオーキングをしたり (歩いたり) しています。

最初は，健康のために運動すること（語学の勉強をすること）は，億劫だと思っていましたが，今ではとても 楽しくて，長く続けていけそうです。

注）太字が操作箇所であり（）外がダイエット目標条件，（）内が勉強目標条件であった。 